Tropical Journal of Pharmaceutical Research September 2019; 18 (9): 1969-1976

ISSN: 1596-5996 (print); 1596-9827 (electronic)

(c) Pharmacotherapy Group, Faculty of Pharmacy, University of Benin, Benin City, 300001 Nigeria.

\title{
High performance thin-layer chromatography and in vitro cytotoxic studies on ethanol extract of Matricaria chamomilla L (Asteraceae) flowers
}

\author{
Mohammed Al Bratty ${ }^{1}$, Lalitha K Govindaram ${ }^{1 \star}$, Neelaveni Thangavel ${ }^{1}$, Hassan \\ A Alhazmi ${ }^{1}$, Angum M M Ibrahim', Vijayalakshmi Maruthamuthu², Ruckmani \\ Kandasamy ${ }^{2}$ \\ ${ }^{1}$ Department of Pharmaceutical Chemistry, College of Pharmacy, Jazan University, Jazan, Kingdom of Saudi Arabia \\ ${ }^{2}$ Department of Pharmaceutical Technology, University College of Engineering, Anna University, Tiruchirapalli, India
}

*For correspondence: Email: kg.lalitha@gmail.com; Tel: +966557469709

Sent for review: 21 March 2019

Revised accepted: 20 August 2019

\begin{abstract}
Purpose: To develop a high performance thin-layer chromatography (HPTLC procedure for quantitation of apigenin in ethanol extract of Matricaria chamomilla (Babunaj) flowers, and to evaluate the extract for in vitro cytotoxic effect on MCF-7 cell lines.

Methods: Quantification of apigenin was carried out using a CAMAG TLC system. A combination of toluene, ethyl acetate and formic acid (4.5:3.5:0.2 v/v/v) was used as mobile phase, with densitometry detection at $336 \mathrm{~nm}$. The HPTLC procedure was subjected to validation as per ICH guidelines. The cytotoxicity of the extract was assessed by 3-(4,5-dimethylthiazol-2-yl)-2,5-diphenyl tetrazolium bromide (MTT) assay.

Results: A sharp apigenin band at Rf of 0.51 was obtained, and the content of apigenin in the extract was $0.062 \% \mathrm{w} / \mathrm{w}$. The detection limit (LOD) and quantification limit (LOQ) were 0.19 and $0.57 \mathrm{ng} / \mathrm{band}$, respectively. MTT assay results indicate that $M$. chamomilla was cytotoxic to Michigan Cancer Foundation-7 (MCF-7) cells, with half-maximal concentration (IC $\left.C_{50}\right)$ of $74 \mu \mathrm{g} / \mathrm{mL}$.

Conclusion: The developed HPTLC method is linear, precise, accurate and specific for the determination of apigenin. M. chamomilla exerts cytotoxic effect on MCF-7 cell line via induction of apoptosis.
\end{abstract}

Keywords: Matricaria chamomilla, HPTLC, Apigenin, MCF-7 cell line, Cytotoxicity

\begin{abstract}
This is an Open Access article that uses a fund-ing model which does not charge readers or their institutions for access and distributed under the terms of the Creative Commons Attribution License (http://creativecommons.org/licenses/by/4.0) and the Budapest Open Access Initiative (http://www.budapestopenaccessinitiative.org/read), which permit unrestricted use, distribution, and reproduction in any medium, provided the original work is properly credited.

Tropical Journal of Pharmaceutical Research is indexed by Science Citation Index (SciSearch), Scopus, International Pharmaceutical Abstract, Chemical Abstracts, Embase, Index Copernicus, EBSCO, African Index Medicus, JournalSeek, Journal Citation Reports/Science Edition, Directory of Open Access Journals (DOAJ), African Journal Online, Bioline International, Open-J-Gate and Pharmacy Abstracts
\end{abstract}

\section{INTRODUCTION}

Traditional medicine plays a pivotal role in the treatment of various diseases. Standardization of herbal drugs is important for validation of biological effects, safety and quality in relation to the chemical constituents of herbal drugs. high performance thin layer chromatography (HPTLC) is the most preferred analytical tool. It is a fast and inexpensive method of analysis used to separate, qualify and quantify a mixture of phytocomponents. 
Breast cancer is a major cause of mortality globally, for which no unified treatment options have emerged till now. Matricaria chamomilla (babunaj in Arabic, chamomile in German; (Family-Asteraceae) is a familiar folk medicine in Saudi Arabia. Studies have shown that it possesses anti-inflammatory, analgesic, antimicrobial, antispasmodic, carminative, antioxidant, hypocholesterolemic, anti-parasitic, anti-aging, anticancer and sedative effects [1-3]. Apigenin glucosides are the major constituents of M. chamomilla [4]. These have been quantified in methanolic extract of chamomile using HPLC, and their cytotoxicity on human prostate cancer PC-3 cell lines have been evaluated [2].

The present study was focused on quantitative estimation of the biomarker apigenin (Figure 1) using HPTLC in a pharmacologically significant herbal species $M$. chamomilla, and validation of the proposed method as per ICH norms $[5,6]$. The present investigation also evaluated the in vitro cytotoxicity of $M$. chamomilla on Michigan Cancer Foundation-7 (MCF-7) cells.<smiles>O=c1cc(-c2ccc(O)cc2)oc2cc(O)cc(O)c12</smiles>

Figure 1: Chemical structure of apigenin

\section{EXPERIMENTAL}

\section{Materials and reagents}

A CAMAG TLC system containing a Linomat $V$ applicator and CAMAG TLC III scanner was utilized for analysis of apigenin. Pre-coated aluminum sheets (silica gel 60F $25420 \times 10 \mathrm{~cm}$ with stationary phase thickness of $250 \mu \mathrm{m}$ ), analytical grade chemicals and solvents were procured from E. Merck, Germany. Standard apigenin was procured from Sigma Aldrich, Saudi Arabia. The MCF-7 human breast cancer cell lines were provided by NCCS, India. They were cultured in DMEM (Sigma Aldrich) supplemented with $10 \%$ FBS (Gibco), penicillin (100 U/mL) and $100 \mu \mathrm{g} / \mathrm{mL}$ streptomycin (Gibco) using 96-well plates in an incubator with $5 \% \mathrm{CO}_{2}$ at $37^{\circ} \mathrm{C}$.

\section{Plant material}

The flowers of $M$. chamomilla (Family Asteraceae) were purchased from Jazan Market, Jazan, and were identified and authenticated by Dr Remesh Moochikkal, Curator of the
Herbarium JAZUH and a sample (no. 1217 JAZUH) was kept in Jazan University Herbarium (JAZUH) for future reference.

\section{Extraction of $M$. chamomilla}

The flowers (200 g) were shade-dried and powdered. The extraction of the powdered flowers using ethanol ( $80 \% \mathrm{v} / \mathrm{v})$ was carried out in Soxhlet apparatus for $72 \mathrm{~h}$. The ethanol extract of $M$. chamomilla (MC) was concentrated under vacua using rota-evaporator.

\section{Preparation of standard solution}

Ten mg of accurately weighed apigenin was dissolved in methanol $(10 \mathrm{~mL})$ by sonication and was further diluted with methanol to attain the concentration of $5 \mathrm{ng} / \mu \mathrm{L}$.

\section{Preparation of sample solution}

Ten $\mathrm{mg}$ of $\mathrm{MC}$ sonicated with $1 \mathrm{~mL}$ methanol (10 $\mu \mathrm{g} / \mu \mathrm{L}$ ) was used for HPTLC analysis. Ten $\mathrm{mg}$ of MC was dissolved in $5 \mathrm{~mL}$ of DMSO and further diluted with DMSO to obtain $10-100 \mu \mathrm{g} / \mathrm{mL}$ solutions which were used for cytotoxic activity.

\section{Preparation of phosphate buffered saline (PBS, pH 7.4)}

Four (4) $\mathrm{g}$ of $\mathrm{NaCl}, 0.1 \mathrm{~g}$ of $\mathrm{KCl}, 0.72 \mathrm{~g}$ of $\mathrm{Na}_{2} \mathrm{HPO}_{3}$, and $0.12 \mathrm{~g}$ of $\mathrm{KH}_{2} \mathrm{PO}_{3}$ were dissolved in $500 \mathrm{~mL}$ of distilled water.

\section{Optimization of mobile phase}

During the optimization of chromatographic conditions, the separation studies were performed using different solvent systems to obtain excellent quality and symmetrical shape of peaks. Trial separations were performed using several solvents of varying polarities i.e. hexane, toluene, chloroform, di-chloromethane and ethyl acetate. Based on the outcome of these trials, binary and tertiary solvent mixtures were tried. The other chromatographic parameters viz., chamber saturation time, height of solvent run, sample loading volume, sample loading rate, space between spots, and detection wavelength were optimized to obtain consistent $R_{f}$ and to resolve phyto-constituents in an improved manner.

\section{Chromatographic conditions}

A continuous loading rate of $100 \mathrm{~nL} / \mathrm{sec}$ and 18.8 $\mathrm{mm}$ of band separation for sample were maintained. The scanning was carried out at 6.00 $\times 0.45 \mathrm{~mm}$ slit dimension and speed of 10 
$\mathrm{mm} / \mathrm{sec}$. The monochromator was maintained at a bandwidth of $20 \mathrm{~nm}$. The scanning of each track was performed in triplicate with baseline correction. The combination of toluene, ethyl acetate and formic acid (4.5:3.5:0.2 v/v/v) was allowed to rise to $80 \mathrm{~mm}$ after $20 \mathrm{~min}$ of optimized chamber saturation time maintained at room temperature $\left(25 \pm 2{ }^{\circ} \mathrm{C}\right)$ and relative humidity of $55 \pm 5 \%$. The average time taken for the development was $15 \mathrm{~min}$. The validation was carried out as per ICH guidelines.

\section{Quantification of apigenin in MC}

The MC and standard solutions in linear range were loaded and studied. The experiment was performed in six replicates. The amount of apigenin present in $\mathrm{MC}$ was computed as jn Eq 1.

Apigenin content $=[(\mathrm{TA} \times \mathrm{SD}) /(\mathrm{SA} \times \mathrm{TD})] \times 100 \ldots(1)$

where $T A$ is the test area, $S D$ is the standard dilution, $S A$ is the standard area and $T D$ is the test dilution.

\section{Validation of the proposed method}

\section{Linearity}

Standard apigenin solution of volumes $2,4,6,8$ and $10 \mu \mathrm{L}$ were loaded in HPTLC plates (10 $50 \mathrm{ng} / \mathrm{band}$ ) and studied. A linearity curve was constructed through a plot of peak area against apigenin content.

\section{Sensitivity}

This was evaluated in terms of LOQ. The lowest concentration detected under the chromatographic conditions was the LOD. Values of LOD and LOQ were determined using Eqs 2 and 3.

$$
\begin{aligned}
& \mathrm{LOD}=3.3 \times \mathrm{N} / \mathrm{B} \ldots \ldots \ldots \ldots(2) \\
& \mathrm{LOQ}=10 \times \mathrm{N} / \mathrm{B} \ldots \ldots \ldots \ldots(3)
\end{aligned}
$$

where $\mathrm{N}$ refers to standard deviation of the peak areas of the drug sample taken as the measure of the noise, while $B$ represents slope of the standard curve.

\section{Precision}

Six replicate loadings of freshly prepared standard at concentrations of 20,40 and 60 $\mathrm{ng} / \mathrm{band}$ were analysed on the same day for intra-day precision, and on three different days for inter-day precision.

\section{Specificity}

The specificity of method was determined by overlaying apigenin in $\mathrm{MC}$ and apigenin in standard spectra.

\section{System suitability}

The resolution and repeatability of the developed method were determined by analysing six repeated loads of fresh standard (40 ng/band). The mean peak area, SD and \% RSD were determined.

\section{Robustness}

Tiny fluctuations in parameters like volume of solvent phase, chamber saturation time and duration of pre-conditioning of plate were introduced in the developed method, and the results were analyzed in triplicates of $40 \mathrm{ng} / \mathrm{band}$. The percentage RSD of peak area was also determined.

\section{Accuracy}

To determine how accurate the proposed method was, three-level recovery studies were carried out using standard addition procedure. Known quantities of standard apigenin (300, 600 and $900 \mathrm{ng}$ ) were added to the $\mathrm{MC}(1 \mathrm{mg})$ and the resultant solutions were analysed.

\section{In vitro cytotoxicity assay}

The viability assay was performed as per Mosmann method [7] using 3-(4, 5 dimethyl thiazol-2-yl)-2, 5 diphenyl $2 \mathrm{H}$-tetrazolium bromide (MTT solution). In this procedure, 10 - 100 $\mu \mathrm{g} / \mathrm{mL}$ of $\mathrm{MC}$ were loaded to the well plates containing 24-h seeded cells at density of $5 \times 10^{3}$ MCF cells/well in $200 \mu \mathrm{L}$ of fresh culture medium. After $24 \mathrm{~h}$, the cells in each well were treated with $20 \mu \mathrm{L}$ MTT solution and incubated at $37^{\circ} \mathrm{C}$ for $4 \mathrm{~h}$ in the dark. Then, $100 \mu \mathrm{L}$ of DMSO was added to each well to dissolve the formazan crystals formed, and absorbance (OD) was measured at $570 \mathrm{~nm}$ in triplicate in 96-well plate reader (Bio Rad, Hercules, CA, USA). Inhibition was calculated using Eq 4.

$\%$ Inhibition $=[($ OC-OT $) / O C] \times 100$

where $\mathrm{OC}$ is the mean absorbance of control, while OT is the mean absorbance of treatment group. 
Acridine orange (AO)/ethidium bromide (EB) staining

Quantification of apoptotic cell death was carried out using $A O$ and EB staining according to the method of Spector et al [8]. The cells treated with $\mathrm{MC}$ and untreated cells were stained with $25 \mu \mathrm{L}$ of $\mathrm{AO} / \mathrm{EB}$ dye and 300 cells were observed in triplicate under UV filter (excitation at $450 \mathrm{~nm}$ \& emission at $490 \mathrm{~nm}$ ) in fluorescent microscope (Carl Zeiss, Germany). The nuclear morphology and membrane integrity of the cells were scored and categorized as viable, apoptotic or necrotic. The percentage of cells in each category was calculated.

\section{Hoechst 33528 staining test}

Nuclear morphological changes were observed with Hoechst 33528 stain as per Latt et al [9]. MCF -7 cells were exposed to MC at levels corresponding to $\mathrm{IC}_{50}$, and incubated for $24 \mathrm{~h}$. Both treated and untreated cells were stained with Hoechst 33258 in PBS for $5 \mathrm{~min}$ at $25^{\circ} \mathrm{C}$. Approximately 300 cells were observed in triplicate at $355 \mathrm{~nm}$ (excitation) and $377 \mathrm{~nm}$ (emission) in a fluorescent microscope.

\section{Reactive oxygen species (ROS) assay}

The generation of intracellular ROS was assessed using 2'7' dichloro dihydro fluorescein diacetate (DCFH-DA) dye [10]. Each well containing $1 \times 10^{6} \mathrm{MCF}-7$ cells was exposed to $\mathrm{MC}$ at $\mathrm{IC}_{50}$ level and incubated for 12 and $24 \mathrm{~h}$. The cells were stained with $5 \mu \mathrm{M}$ of DCFH-DA and incubated for $30 \mathrm{~min}$ at $37^{\circ} \mathrm{C}$. Thereafter, they were analyzed using a spectrofluorimeter at $485 \mathrm{~nm}$ (excitation) and $520 \mathrm{~nm}$ (emission).

\section{Statistical analysis}

The results from analytical and in vitro assays are presented as mean \pm standard deviation.

\section{RESULTS}

\section{Validated HPTLC method}

The extract of MC yielded $0.7 \mathrm{~g}$ residue which was used for the in vitro cytotoxicity study and for quantification of apigenin using HPTLC method. The developed HPTLC method gave an apigenin peak with $R_{f} 0.51$. Chromatograms of standard and $M C$ are shown in Figures $2 \mathrm{~A}$ and $2 \mathrm{~B}$, respectively. The amount of apigenin in $M C$ was $0.062 \%(\mathrm{w} / \mathrm{w})$ at detection wavelength of $336 \mathrm{~nm}$ (Figure 2C). The linearity curve in the range 10 to $50 \mathrm{ng} /$ band of apigenin is shown in Figure 2D. The values of intercept, correlation coefficient, and slope were 1058.5, 0.999, and 1632.2, respectively. The LOD and LOQ values were 0.19 and $0.57 \mathrm{ng}$, respectively, which indicated adequate sensitivity of the method. The apigenin peak of the extract was identified through comparison of its $R_{f}$ and absorbance spectrum with those of the standard.
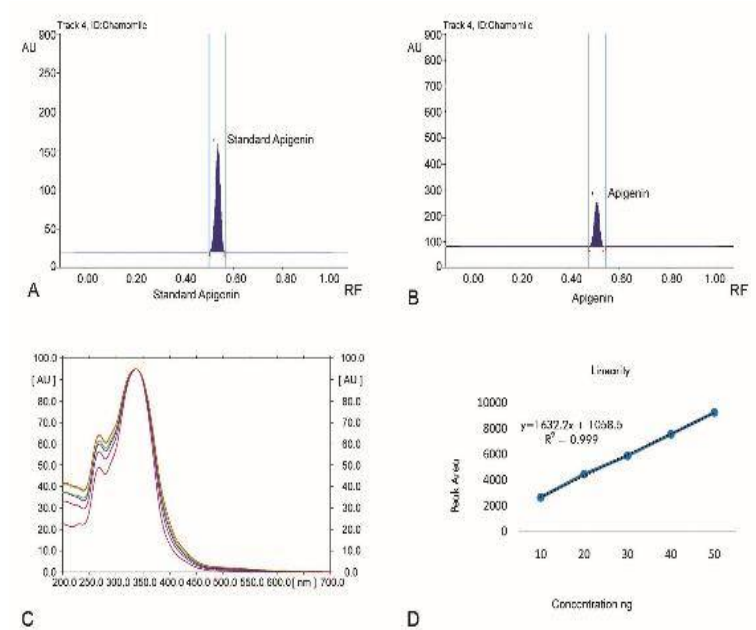

Figure 2: HPTLC quantification of apigenin. A: Chromatogram of standard apigenin; B: chromatogram of MC; C: UV spectra of standard on linearity; D: linearity curve

Peak areas at 3 different apigenin concentrations showed low \% RSD from 0.30 to 0.61 ( $<2 \%)$ with respect to inter- and intra-day fluctuations, suggesting excellent precision (Table 1). The accuracy of the method analysed through percentage recovery of apigenin showed values of 98.26 to $100.05 \%$ (Table 2), which were within the acceptable limits (98.0 to $102.0 \%)$. The low values of SD and \% RSD (Table 3) obtained after introducing small deliberate changes in the developed method indicated the robustness of the method.

Table 1: Intra-day precision data for apigenin

\begin{tabular}{lcccc}
\hline $\begin{array}{l}\text { Apigenin } \\
\text { concentration } \\
\text { (ng/band) }\end{array}$ & $\begin{array}{c}\text { Intra-day precision } \\
\text { Concentration found } \\
\text { (ng/band) (Mean } \mathbf{S} \boldsymbol{S D})\end{array}$ & \%RSD & $\begin{array}{c}\text { Concentration found } \\
\text { (ng/band) (Mean } \pm \text { SD) }\end{array}$ & \%RSD \\
\hline 10 & $10.03 \pm 0.06$ & 0.60 & $10.08 \pm 0.09$ & 0.92 \\
20 & $20.10 \pm 0.12$ & 0.58 & $20.00 \pm 0.07$ & 0.37 \\
30 & $30.06 \pm 0.06$ & 0.19 & $30.00 \pm 0.09$ & 0.29 \\
\hline
\end{tabular}


Table 2: Recovery data for apigenin from MC

\begin{tabular}{lcccc}
\hline $\begin{array}{l}\text { Percent of } \\
\text { standard apigenin } \\
\text { added }\end{array}$ & $\begin{array}{c}\text { Theoretical } \\
\text { calculation }(\mathbf{n g})\end{array}$ & $\begin{array}{c}\text { Amount found } \\
\mathbf{( n g )}\end{array}$ & RSD (\%) & Recovery (\%) \\
\hline 50 & 921.7 & $905.3 \pm 0.21$ & 1.85 & 98.26 \\
100 & 1221.7 & $1198.9 \pm 0.19$ & 1.29 & 98.10 \\
150 & 1521.7 & $1521.9 \pm 0.26$ & 1.37 & 100.05 \\
\hline
\end{tabular}

Table 3: Robustness data

\begin{tabular}{lcc}
\hline $\begin{array}{l}\text { Optimization } \\
\text { conditions }\end{array}$ & \multicolumn{2}{c}{ Apigenin $20 \begin{array}{c}\text { (ng/band) } \\
\% \text { RSD }\end{array}$} \\
\hline $\begin{array}{l}\text { Mobile phase volume } \\
18 \mathrm{~mL}\end{array}$ & \\
$20 \mathrm{~mL}$ & $19.99 \pm 0.11$ & 0.57 \\
$22 \mathrm{~mL}$ & $19.98 \pm 0.10$ & 0.50 \\
Saturation time & & 0.30 \\
$18 \mathrm{~min}$ & $20.00 \pm 0.11$ & 0.58 \\
$20 \mathrm{~min}$ & $20.03 \pm 0.12$ & 0.61 \\
$22 \mathrm{~min}$ & $20.03 \pm 0.09$ & 0.46 \\
Duration of pre-conditioning of plate & \\
$3 \mathrm{~min}$ & $20.01 \pm 0.10$ & 0.50 \\
$5 \mathrm{~min}$ & $19.99 \pm 0.09$ & 0.43 \\
$7 \mathrm{~min}$ & $20.02 \pm 0.11$ & 0.55 \\
\hline
\end{tabular}

With respect to suitability, the RSD of apigenin peak areas and $R_{f}$ values as calculated were 1.29 and 0.11 , respectively which were within the acceptable limits $(<2)$. This indicates that the developed method is suitable for the intended purpose.

\section{In vitro cytotoxicity}

Figure $3 \mathrm{~A}$ shows the inhibitory effect of $\mathrm{MC}$ and corresponding concentrations $(10-100 \mu \mathrm{g} / \mathrm{mL})$ at which it was cytotoxic to MCF-7 cell line. The cytotoxic effect was exerted in a dose-dependent manner. The inhibitory concentration $\left(\mathrm{IC}_{50}\right)$ value was $74 \mu \mathrm{g} / \mathrm{mL}$.

\section{$A O / E B$ stain}

Apoptotic features were measured in various cellular alterations. Based on the viability and membrane integrity of the cells, dead cells allow EB dye and fluoresce orange red while live cells are very selective and allow only $A O$, resulting in green fluorescence. Four types of cytological changes perceived on MC-exposed cells were: (a) viable cells showed ordered nuclei, and fluoresced green; (b) early apoptotic cells showed nuclear condensation and produced orange green fluorescence; (c) the nuclei of late apoptotic cells had chromatin condensation and fragmentation, and emitted orange-to-red fluorescence; (d) necrotic cells fluoresced orange-to-red with no sign of fragmented chromatin. Figure 3B shows the percentages of apoptotic and necrotic cells produced by $\mathrm{MC}$ at its $\mathrm{IC}_{50}$ after $24 \mathrm{~h}$.

\section{Hoechst 33528 stain}

After $24 \mathrm{~h}$ of MC treatment, the MCF 7 cells showed condensation and chromatin fragmentation, indicating that $M C$ exerted necrosis through an apoptotic mechanism. The nuclei of control cells were even and firm, with regular discrete chromatin. Figure $3 \mathrm{C}$ shows the bar graph of MC-induced abnormal nuclei and the percentage of cells. Figure 4 shows fluorescence micrograph of the MC-induced apoptotic cells and nuclear morphology after $24 \mathrm{~h}$ at its $\mathrm{IC}_{50}$.
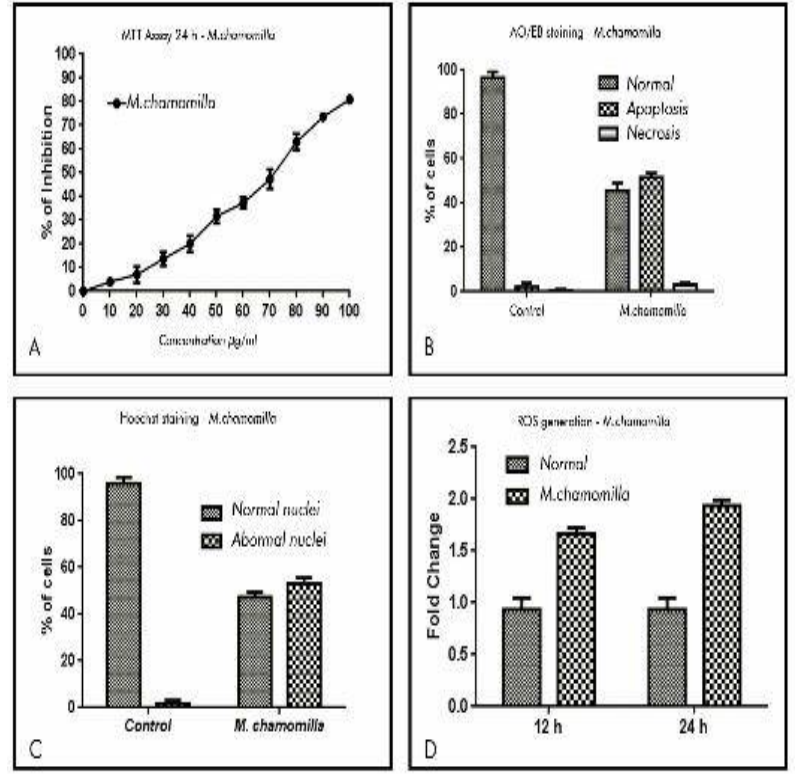

Figure 3: Cytotoxicity studies of MC on MCF cell lines. A: MTT assay; B: AO/EB staining; C: Hoechst staining; D: Duration raise of ROS generation

\section{Reactive oxygen species}

The generation of ROS is related to mitochondria-mediated apoptosis. Indeed, ROS have been proposed as probable mediators of apoptosis. In MCF-7 cells treated with MC at the level of its $\mathrm{IC}_{50}$, intracellular ROS was increased in a concentration- and time-dependent manner (Figure 3D). 

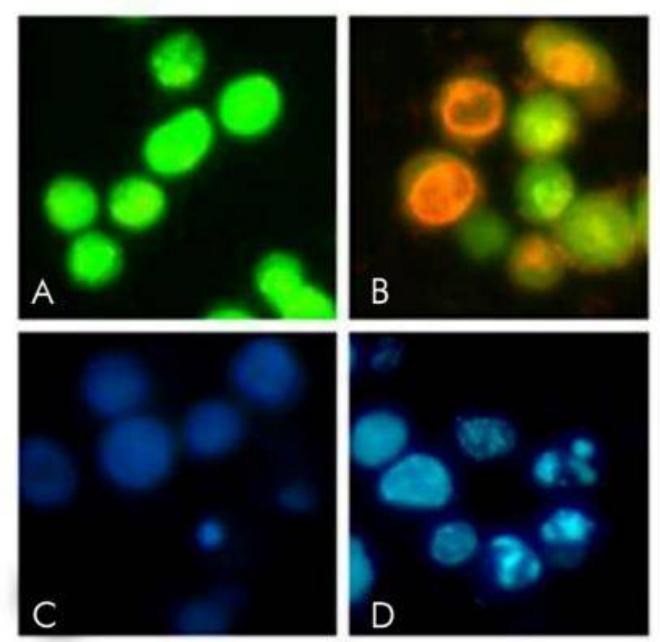

Figure 4: Fluorescence micrograph of $M C$ in $M C F$ cell lines. $A: A O / A B$ stain in control; $B: A O / A B$ stain in $M C$; C: Hoechst stain in control; D: Hoechst stain in $M C$

\section{DISCUSSION}

The flowers obtained from Jazan market were identified as German chamomile. This variety of chamomile is widely for therapeutic purposes. Previous reports suggest that there are possibilities of adulteration of chamomile flowers with other flowers which have close physical similarity to chamomile. Therefore, it is necessary to employ a suitable analytical technique for rapid quality control of chamomile flowers. Matricaria chamomilla contains various bioactive phenolic compounds such as flavonoids and flavonoid glycosides. Apigenin and apigenin-7-O-glucoside are the frequently detected flavonoids in aqueous and methanolic extracts of the plant [2].

There are very few reported analytical methods for the quantification of flavonoids in chamomile. An HPTLC method for the quantification of apigenin-7-O-glucoside has been reported $[11,12]$. A high-performance Liquid chromategraphy method and an UHPLC have been reported for the quantification of apigenin in other varieties of chamomile $[13,14]$. This study is the first report of HPTLC analysis of German chamomile flowers for quantification of apigenin. Since the presence of apigenin was reported in aqueous and methanolic extracts, the apigenin content of MC was quantified in the present study. MC contains the anticancer bio-marker apigenin. The amount of apigenin present in the MC was successfully quantified with the HPTLC method using toluene, ethyl acetate and formic acid in the ratio of 4.5: 3.5: $0.2(\mathrm{v} / \mathrm{v} / \mathrm{v})$ as mobile phase. The amount of apigenin present in $M C$ was $0.062 \%(w / w)$. Quercetin and apigenin are the major flavonoids $n$ chamomile [11]. They are responsible for anti-cancer effect of chamomile [15-17]. Apigenin-7-O-glucoside has also been shown to exert anti-cancer effect [2]. Apigenin induces apoptosis in different cancer cells [1820]. In vitro studies on extracts of different parts of $M$. chamomilla revealed that they induced apoptosis in different cancer cells, with high $\mathrm{IC}_{50}$ values $[16,17]$. The MC from Jazan was cytotoxic to MCF-7 breast cancer cells at an $\mathrm{IC}_{50}$ of 74 $\mu \mathrm{g} / \mathrm{mL}$ which was low when compared to other varieties with $\mathrm{IC}_{50}$ values of 1288 and 1954 $\mu \mathrm{g} / \mathrm{mL}[16,17]$. This indicates that German chamomile may be more potent in controlling breast cancer than the other reported species. Moreover, MTT results revealed that the reduction of cell viability by the MC was dosedependent. The MTT method qualitatively assesses cell growth and necrosis through the viability of the mitochondrion. The apoptosisinduced cytotoxic effect was observed not only by decrease in cell viability but also by fragmentation of DNA, membrane blebbing and chromatin condensation.

One important apoptotic process involves condensing of chromatin, and it is studied using Hoechst 33342 chromatin condensation staining method. There were deviations in distinctive apoptotic nuclear morphology in MC-exposed cells, relative to controls. The normal cells without apoptosis had no evidence of chromatin condensation, unlike cells that underwent apoptosis. The lower $\mathrm{IC}_{50}$ values suggest that MC toxicity was more potent in cells with DNA damage than in non-damaged cells. Several reports have revealed that apoptosis is related to the ROS levels in cancer tissues.

Reactive oxygen species perform dual physiological functions: they are involved in signal transductions at low levels, but at higher levels, they enhance apoptosis. Many researchers have reported faster accessibility of ROS to cancer tissues than healthy ones [21,22]. In this study, MC caused marked internalization of ROS and cell death, thereby confirming that ROS induced apoptotic changes in MCF-7 cell line. Results of fluorescent microscopic analysis indicated that $\mathrm{MC}$ was able to induce more apoptosis than necrosis in breast cancer cells.

\section{CONCLUSION}

A HPTLC method has successfully been developed and validated for the quantification of apigenin in MC. The method can also be applied as a quality control tool and thus can facilitate the standardization of plant-based medicines for defined content of bio-actives to ensure their quality and safety. The findings of this study also 
show that MC exerts potent effect against MCF-7 cells. Further studies are required to correlate the cytotoxic effect of the plant material with the content of apigenin and other phenolic compounds in MC.

\section{DECLARATIONS}

\section{Acknowledgement}

We thank the Deanship of Scientific Research, Jazan University, Jazan, for funding the research project, JUP8//00413.

\section{Conflict of interest}

No conflict of interest is associated with this work.

\section{Contribution of authors}

We declare that this work was done by the authors named in this article and all liabilities pertaining to claims relating to the content of this article will be borne by the authors.

\section{Open Access}

This is an Open Access article that uses a funding model which does not charge readers or their institutions for access and distributed under the terms of the Creative Commons Attribution License (http://creativecommons.org/licenses/by/ 4.0) and the Budapest Open Access Initiative (http://www.budapestopenaccessinitiative.org/rea d), which permit unrestricted use, distribution, and reproduction in any medium, provided the original work is properly credited.

\section{REFERENCES}

1. Donia AM, Aftab A, Nour YS, Radwan AM. Evaluation of antimicrobial and antioxidant activities of Matricaria recutita, Ricinus communis and Zygophyllum coccineum extracts. Bull Env Pharmacol Life Sci 2016; 5(7): 30-33.

2. Srivastava JK, Gupta S. Extraction, characterization, stability and biological activity of flavonoids isolated from chamomile flowers. Mol Cell Pharmacol 2009; 1(3):138147.

3. Gardiner P. Complementary, holistic and integrative medicine: chamomile. Pediatr Rev 2007; 28: 16-18.

4. Srivastava JK, Gupta S. Antiproliferative and apoptotic effects of chamomile extract in various human cancer cells. J Agric Food Chem 2007; 55: 9470-9478.

5. ICH, Q2B, and (R1): Validation of analytical procedures: Text and methodology, Federal Register 1996.

6. ICH, Q2, and (R1): Validation of analytical procedures: Text and methodology, Geneva 2005.
7. Mosmann T. Rapid colorimetric assay for cellular growth and survival: application to proliferation and cytotoxicity assays, J Immunol Methods 1983; 65: 55-63.

8. Spector $D L$, Goldman RD, Leinwand LA. Cell: $A$ laboratory manual, culture and biochemical analysis of cells. New York: Cold Spring Harbor Laboratory Press; 1998. (1) p. 34.1-34.9.

9. Latt $S A$, Stetten $G$, Juergens $L A$, Willard HF, Scher $C D$. Recent developments in the detection of deoxy ribonucleic acid synthesis by 33258 Hoechst fluorescence. J Histochem Cytochem 1975; 23: 493505.

10. Wang H, Joseph JA. Quantifying cellular oxidative stress by dichloro fluorescein assay using microplate reader. Free Radic Biol Med 1999; 27: 612-616.

11. Guzelmeric E, Vovk I, Yesilada E. Development and validation of an HPTLC method for apigenin 7-Oglucoside in chamomile flowers and its application for fingerprint discrimination of chamomile like materials, $J$ Pharm Biomed Anal 2015; 107: 108-117.

12. Guzelmeric E, Ristivojevic P, Vovk I, Milojkovic-Opsenica $D$, Yesilada E. Quality assessment of marketed chamomile tea products by a validated HPTLC method combined with multivariate analysis. I Pharm Biomed Anal 2017; 132 (5): 35-45.

13. Miguel FG, Cavalheiro AH, Spinola NF, Ribeiro DL, Barcelos GRM, Antunes LMG, Hori JI, MarqueleOliveira $F$, Rocha $B A$, Berretta $A A$. Validation of a $R P$ HPLC-DAD method for Chamomile (Matricaria recutita) Preparations and assessment of the marker, apigenin-7glucoside, safety and anti-inflammatory effect. Evid Based Complement Alternat Med 2015; http://dx.doi.org/10.1155/2015/828437 9 pages.

14. Novakova L, Vildova A, Mateus JP, Gonçalves T, Solich $P$. Development and application of UHPLC-MS/MS method for the determination of phenolic compounds in Chamomile flowers and Chamomile tea extracts. Talanta 2010; 82(4): 1271-1280.

15. Wang $T, L i$ G, Bi K. Bioactive flavonoids in medicinal plants: Structure, activity and biological fate. Asian J Pharm Sci 2018; 13: 12-18.

16. Nikseresht M, Kamali AM., Rahimi HR, Delaviz H, Toori $M A$, Kashani IR, Mahmoudi $R$. The hydroalcoholic extract of Matricaria chamomilla suppresses migration and invasion of human breast cancer MDA-MB-468 and MCF-7 cell lines. Pharmacognosy Res 2017; 9(1): 8795.

17. Kamali A, Nikseresht M, Delaviz H, Barmak MJ, Servatkhah M, Ardakani MT, Mahmaudi R. In vitro cytotoxic activity of Matricaria Chamomilla root extract in human breast cancer cell line MCF-7. Life Sci 2014; 11: 403-406.

18. Choudhury D, Ganguli A, Ghosh Dastidar D, Acharya BR, Das A, Chakrabarti G. Apigenin shows synergistic anticancer activity with curcumin by binding at different sites of tubulin. Biochimie 2013; 30: 1-13.

19. Vargo MA, Voss OH, Poustka F, Cardounel AJ, Grotewold E, Doseff Al, Apigenin-induced-apoptosis is

Trop J Pharm Res, September 2019; 18(9): 1975 
mediated by the activation of PKC delta and caspases in leukemia cell. Biochem Pharmacol 2006; 72: 681-692.

20. Lee WJ, Chen WK, Wang CJ, Lin WL, Tseng TH. Apigenin inhibits HGF-promoted invasive growth and metastasis involving blocking PI3K/Akt pathway and beta 4 integrin function in MDA-MB-231 breast cancer cells. Toxicol Appl Pharmacol 2008; 226: 178-191.
21. Park E, Bae W, Eom S, Kim K, Paiik H. Improved antioxidative and cytotoxic activities of chamomile (Matricaria chamomilla) florets fermented by Lactobacillus plantarum KCCM 11613P. J Zhejiang Univ Sci B (Biomed \& Biotechnol) 2017; 18(2): 152-160.

22. Li B, Wang CZ, He TC, Yuan CS, Du W. Antioxidants potentiate American ginseng-induced killing of colorectal cancer cells. Cancer Lett 2010; 289(1): 62-70. 